\title{
ANALISIS PEDAGOGICAL CONTENT KNOWLEDGE (PCK) MAHASISWA PEREMPUAN CALON GURU DALAM PEMBELAJARAN MATEMATIKA DITINJAU DARI PERBEDAAN PRESTASI AKADEMIK
}

Awaluddin Makaraka1', Ma'rufi², Muhammad Ilyas ${ }^{3}$

Universitas Cokroaminoto Palopo ${ }^{1,2,3}$

Email: amakkaraka@gmail.com¹, marufi@uncp.ac.id²,muhammadilyas@uncp.ac.id³

\begin{abstract}
Abstrak. Tujuan dari penelitian ini untuk mendeskripsikan Pedagogical Content Knowledge (PCK) mahasiswa perempuan calon guru Matematika terkait aspek- aspek PCK, baik pengetahuan materi, pengetahuan pedagogi dan pengetahuan tentang siswa pada pembelajaran materi Trigonometri di SMA. Penelitian ini merupakan penelitian kualitatif deskriptif. Subyek penelitian melibatkan dua orang mahasiswa perempuan calon guru Matematika yang melaksanakan kegiatan magang tiga di SMA Negeri 1 Palopo. Teknik pengumpulan data dilakukan dengan observasi proses pembelajaran di kelas dengan perekaman video menggunakan handycam. Data dianalisis dengan langkah-langkah yaitu: reduksi data, kategorisasi data, kesimpulan. Penelitian ini mengungkapkan bahwa mahasiswa calon guru dapat menjelaskan fakta, konsep dan aspek prosedural pada materi trigonometri begitupun ada aspek pengorganisaian dan penerapan startegi pembelajaran dengan tingkatan yang berbeda antara kedua subjek. Temuan selanjutnya mahasiswa perempuan calon guru mengalami kesulitan mengidentifikasi sumber kesulitan pemahaman konsep siswa sekaligus tak mampu menemukan cara yang efektif mengatasi kesalahpahaman siswa. Hal ini menyebabkan kesulitan calon guru untuk mengatasi miskonsepsi siswa yang sering terjadi dengan prosedur dan aturan matematis yang tepat dan lebih fokus pada keterampilan menyelesaikan contoh soal daripada memperbaiki kesulitan pemahaman konsep dan mengatasi miskonsepsi yang sering muncul.
\end{abstract}

\section{Kata kunci: Pedagogical Content Knowledge (PCK), Mahasiswa Calon Guru, Pembelajaran Matematika}

\begin{abstract}
This research aimed at describing Pedagogical Content Knowledge (PCK) of female students of Mathematics teacher candidate related to aspe of PCK, whether about matter knowledge, pedagogical knowledge, or knowledge about students in learning of trigonometry matter in SMA. This research was descriptive qualitative research. The subjects of the research were two female students of Mathematics teacher candidate who conducted apprentice activity at SMA Negeri 1 Palopo. Technique of collecting data was conducted by observing learning process in classroom with video recording by using handy cam. Data was analyzed by the following steps: data reduction, data categorization, and conclusion. This research shows that the students of teacher candidate can explain fact, concept and procedural aspect of trigonometry matter. It is the same as organization aspect and implementation of learning strategy with different level between both of subjects. The next finding is that the female students of teacher candidate are difficult to identify the difficulty source of student concept comprehension and they cannot find effective way to overcome students' misunderstanding. This case causes the difficulty of teacher candidate to overcome students' misconception which often happens by procedure and appropriate mathematics rule and more focus to skill in accomplishing example of question than fix difficulty of concept comprehension and overcome misconception which often appears.
\end{abstract}

Keywords: Pedagogical Content Knowledge (Pck), Students of Teacher Candidate, Mathematics Learning.

\section{A. Pendahuluan}

Kemampuan komunikasi matematis peserta didik dapat dikembangkan melalui proses pembelajaran di sekolah, salah satunya adalah proses pembelajaran matematika. Hal ini terjadi karena salah satu unsur dari matematika adalah ilmu logika yang mampu mengembangkan kemampuan berpikir peserta didik. 
Undang-Undang guru dan dosen nomor 14 tahun 2005 dijelaskan tugas guru sebagai pendidik profesional diantaranya adalah mendidik, mengajar, membimbing, mengarahkan, melatih, menilai dan mengevaluasi peserta didik (Undang-Undang Republik Indonesia nomor 14 tahun 2005). Guru merupakan tulang punggung pendidikan sekaligus menjadi komponen utama yang sangat menentukan keberhasilan pendidikan. Guru dalam menjalankan tugas utamanya dituntut untuk dapat melakukan perannya secara maksimalCalon guru yang profesional harus memiliki berbagai kompetensi yang dibutuhkan untuk menjadi pendidik sekaligus pengajar yang baik. Komptensi tersebut diantaranya yakni kompetesi profesional, kompetensi pedagogik, kompetesi sosial dan komptensi kepribadian (Peraturan Pemerintah Republik Indonesia Nomor 74 Tahun 2008 pasal 3).

Kompetensi pedagogik dan kompetensi professional merupakan kompetensi yang sangat penting dimiliki oleh guru dan calon guru. Kompetensi pedagogic merupakan kemampuan guru dalam mengajar sedangkan kompetensi professional merupakan pemahaman guru terhadap materi. Menurut Loughran(2001) Perpaduan antara kompetensi profesional (content knowledge) dan kompetensi pedagogik (pedagogical knowledge) disebut sebagai Pedagogical Content Knowledge (PCK)

Menurut Turnuklu (2012) bahwa PCK merupakan pengetahuan dasar alami untuk mengubah materi pelajaran yang diberikan menjadi bentuk yang dapat dipahami peserta didik. Dasar PCK dibangun dari perpaduan antara pedagogik guru dan pemahaman materi dari seorang guru, sehingga PCK guru dapat mempengaruhi bagaimana cara terbaik seorang guru mengajar dan akan membuat peserta didik dapat memahami ilmu yang diajarkan Loughran (2001) matematika merupakan salah satu materi yang dalam mengajarkannya perlu kemampuan konten dan pedagogik yang memadai. Menurut Ma'rufi, Budayasa,\& Juniati, (2018) Seorang guru harus menguasai konten matematika diajarkan dan tahu cara mentransfer pelajaran sehingga siswa dapat memahaminya dengan mudah.

Menurut Hawkins dalam Ma'rufi \& Ilyas, (2017) bahwa terdapat tiga komponen pengetahuan utama yang esensial bagi guru dalam pembelajaran matematika. Ketiga komponen tersebut, yaitu: (1) Knowledge of Mathematics Knowledge of Teaching, dan (3) Knowledge of Students. Berdasarkan uraian tersebut, Penelitian ini bertujuan untuk mengkaji knowledge of student mahasiswa calon guru dalam pembelajaran trigonometri di SMA.

Pedagogical Content Knowledge (PCK) menurut Marufi (2017) terdiri dari tiga komponen PCK dan setiap komponen memiliki beberapa kategori sebagaimana yang tergambar pada table 1 di bawah ini.

Tabel 1. Komponen dan kategori dari Pedagogical Content Knowledge (PCK)

\begin{tabular}{ll}
\hline Komponen PK & \multicolumn{1}{c}{ Kategori } \\
\hline \multirow{2}{*}{ Knowledge of Subject Matter } & Pengetahuan Faktual \\
(KSM) & Pengetahuan konseptual \\
& Pengetahuan Prosedural \\
Knowledge of Pedagogy & Perencanaan dan pengorganisasian \\
(KP) & pembelajaran \\
Knowledge of Students & Penerapan Strategi Pembelajaran \\
(KS) & Kesalahan dan miskonsepsi siswa \\
\hline
\end{tabular}

Berdasarkan uraian tersebut, Penelitian ini bertujuan untuk menganalisis pedagical content knowledge mahasiswa perempuan calon guru dalam pembelajaran matematika ditinjau dari perbedaan prestasi akademik. 


\section{B. Metode Penelitian}

Jenis penelitian ini adalah penelitian deskripsi kualitatif yang bertujuan untuk mendeskripsikan pedagical content knowledge mahasiswa perempuan calon guru dalam pembelajaran matematika pada materi Trigonometri ditinjau dari perbedaan prestasi akademik. Penelitian ini dilaksanakan di SMA Negeri 1 Palopo. Subjek penelitian ini adalah mahasiswa program studi pendidikan matematika Fakultas Keguruan dan Ilmu Pendidikan Universitas Cokroaminoto Palopo angkatan 2016 yang sedang melaksanakan magang III. Subjek penelitian ini yaitu 2 mahasiswa perempuan. Satu mahasiswa dengan prestasi akademik tinggi dimana memiliki Indeks Prestasi Kumulatif (IPK) lebih dari 3,75 dan satu mahasiswa dengan prestasi akademik sedang dimana memiliki Indeks Prestasi Kumulatif (IPK) antara lebih dari 3,0 dan kurang dari 3,75. Masing - masing subjek yang dipilih akan melakukan proses pembelajaran sebanyak 2 pertemuan. Instrumen penelitian ini terbagi 2 yaitu 1) intrumen utama adalah peneliti sendiri dan 2) instrumen pendukung yaitu lembar observasi. Tehnik pengumpulan data dalam penelitian ini adalah dengan mengobservasi proses yang dilakukan subjek selama pembelajaran dikelas. Tahapan analisis data yaitu reduksi data, kategorisasi/klasifikasi data, interpretasi data, dan penarikan kesimpulan. Untuk mengecek keabshan data dilakukan tehnik triangulasi dengan jenis triangulasi waktu.

\section{Hasil Penelitian}

Hasil penelitan dapat dilihat dari tabel perbandingan setiap kemampuan pada pertemuan 1 dan pertemuan 2. Untuk pengetahuan materi (PM) mahasiswa perempuan calon guru dengan prestasi akademik tinggi dapat dilihat dari tabel berikut :

Tabel 2. Proses Validasi Data Pengetahuan Konseptual Subjek Berkemampuan Akademik Tinggi pada Pembelajaran 1 dan Pembelajaran 2

\begin{tabular}{lll}
\hline SPTPK1 & SPTPK2 \\
\hline Subjek memulai dengan mengajukan pertanyaan & Subjek menggunakan LK dalam menyelesaikan setiap \\
untuk membangun pemahaman awal daan & masalah yang diikuti dengan pertanyaan yang \\
menggunakan LK untuk memahami dan berkaitan dengan cara dalam menemukan luas segitiga & perbandingan \\
mengarah,siswa baik itu dalam mengingatkan & $\begin{array}{l}\text { menggunakan metode } \\
\text { maupun dalam megetahui garis tinggi (STP1-008) }\end{array}$ trigonometri.(SPT2-009) \\
\hline Subjek membimbing siswa melalui pertanyaan- & Subjek membimbing siswa melalui pertanyaan- \\
pertanyaan khusus, sehingga siswa dapat mengetahu & pertanyaan khusus, sehingga siswa dapat mampu \\
garis tinggi dan garis bagi terhadap segitiga.(SPT1- & $\begin{array}{l}\text { memahami penyelesaian permasalahan mengenai luas } \\
\text { 005, SPT1-008, SPT1-11, SPT1-014) }\end{array}$ & segitiga (SPT1-009, SPT2-011, SPT2-015) \\
\hline
\end{tabular}

Untuk pengetahuan pedagogi (PP) mahasiswa perempuan calon guru dengan prestasi akademik tinggi dapat dilihat dari tabel berikut:

Tabel 3. Proses Validasi Data Pengorganisasian Pembelajaran Subjek Berkemampuan Akademik Tinggi pada Pembelajaran 1 dan Pembelajaran 2

\section{SPTPB1}

Subjek membagi siswa ke dalam beberapa kelompok kecil, siswa bersama mendiskusikan dan mengerjakan LK yang diberikan. (SPT1-002)

Subjek menyampaikan materi yang akan dipelajari kepada siswa.(SPT1-002)

Subjek memberikan LKPD kepada setiap kelompok, mengarahkan siswa untuk mengisi biodata kelompok pada LK. Dan menngarahkan siswa untuk bersama-sama mendiskusikan LK yang dibeikan. (SPT1-002)

\section{SPTPB2}

Subjek mengarahkan siswa untuk duduk

berdasarkan kelompok yang telah dbuat. SPT2-003

Subjek menyampaikan materi yang akan dipelajari kepada siswa. (SPT2-005)

Subjek memberikan LKPD kepada tiap

kelompoknya agar siswa bekerjasama mengerjakan

LK yang diberikan (SPT2-005) (SPT2-006) 
Untuk pengetahuan tentang siswa (PS) mahasiswa perempuan calon guru dengan prestasi akademik tinggi dapat dilihat dari tabel berikut :

Tabel 4. Proses validasi data subjek pada pertemuan 1 dan pertemuan 2 dalam mengatasi miskonsepsi

\section{SPTPM1}

subjek membimbing subjek untuk mengganti

bentuk $\mathrm{x}^{2}$ ke dalam bentuk $\mathrm{C}^{2}-\mathrm{AD}^{2}$ (STP1-055).

Subjek memberikan beberapa pertanyaan dan

petunjuk kepada siswa untuk membuktikan aturan

cosinus (STP1-058)

SPTPM2

Subjek mengatasi kesulitan siswa dengan mengulang kembali materi yang telah di ajarkan pada pertemuan sebelumnya (STP2-009). Subjek membimbing siswa dengan cara mengajukan sejumlah pertanyaan singkat dan bersifat menuntun (STP2-010, STP2-011,STP2-012,STP2-013,STP2014)

Validasi data subjek dalam mengatasi miskonsepsi siswa pada Tabel 6, menunjukkan bahwa terdapat konsistensi subjek dalam mengatasi miskonsepsi siswa. Kesulitan-kesulitan yang dialami siswa disebabkan karena pemahaman siswa yang tidak matang terhadap materi segitiga dan penentuan luasnya. Kelemahan ini terjadi karena siswa tidak mampu menghubungkan konsep segitiga siku-siku ke dalam bentuk aturan cosinus.

Subjek mengatasi kesulitan yang dialami siswa dengan mengulang kembali materi yang diajarkan pada pertemuan sebelumnya. Selain dengan mengulang materi yang telah dipelajari, subjek juga mengatasi kesulitan yang dialami siswa dengan tehnik bertanya. Teknik bertanya kepada siswa juga digunakan subjek ketika mengeksplorasi rumus phytagoras dan mensubstitusikannya ke bentuk aturan cosinus. Teknik bertanya juga digunakan subjek untuk membimbing siswa dalam menyelesaikan masalah yang diberikan. Sehingga miskonsepsi siswa dapat diminimalisir.

Sedangkan untuk subjek ke 2 yaitu mahasiswa perempuan calon guru dengan prestasi akademik sedang pada aspek pengetahuan materi (PM) dapat dilihat dari tebel berikut :

Tabel 5. Proses Validasi Data Pengetahuan Konseptual Subjek Berkemampuan Akademik Sedang pada Pembelajaran 1 dan Pembelajaran 2

\begin{tabular}{ll}
\hline SPSPK1 & SPSPK2 \\
\hline $\begin{array}{l}\text { Subjek menjelaskan secara umum mengenai } \\
\text { ukuran sudut dengan menggunakan dua cara yaitu } \\
\text { derajat dan radiant (SPS1-026) }\end{array}$ & $\begin{array}{l}\text { Subjek menjelaskan dan memperkenalkan mengenai } \\
\text { perbandingan trigonometri terhadap suatu segitiga } \\
\text { siku-siku (SPS2-009) }\end{array}$ \\
\hline $\begin{array}{l}\text { Subjek menjelaskn dengan mengarahkan siswa } \\
\text { dalam menyelesaikan suatu permasalah yang }\end{array}$ & $\begin{array}{l}\text { Subjek meberikan suatu pemahaman mengenai suatu } \\
\text { perbandingan trigonometri dengan penyelasain }\end{array}$ \\
dinyatakan dalam bentuk satuan menit (SPS1- & $\begin{array}{l}\text { menggunakan teorema phitagoras (SPS2-013, SPS2- } \\
\text { 027, SPS1-034) }\end{array}$ \\
\hline
\end{tabular}

Untuk pengetahuan pedagogi (PP) mahasiswa perempuan calon guru dengan prestasi akademik sedang dapat dilihat dari tabel berikut :

Tabel 6. Proses Validasi Data Pengorganisasin Pembelajaran SPS pada Pembelajaran 1 dan Pembelajaran 2

\section{SPSPB1}

Subjek membagi siswa ke dalam beberapa kelompok kecil dan membagikan LKPD kepada masing-masing kelompok. (SPS1-005)

Subjek menyampaikan materi yang akan dipelajari kepada siswa.(SPT1-004)

\section{SPSPB2}

Subjek mengarahkan siswa untuk duduk berdasarkan kelompok yang telah dibuat sebelumnya, siswa bersama mendiskusikan dan mengerjakan soal latihan yang diberikan. (SPS2-053)

Subjek menanyakan kepada siswa materi yang telah dipelajari pekan lalu dan menyampaikan materi yang akan dipelajari. (SPS2-002, SPS2-004) 
Untuk pengetahuan tentang siswa (PS) mahasiswa perempuan calon guru dengan prestasi akademik tinggi dapat dilihat dari tabel berikut :

\begin{tabular}{|c|c|}
\hline SPSPM1 & SPSPM2 \\
\hline $\begin{array}{l}\text { Siswa mengalami kesulitan dalam mengubah } \\
\text { besaran sudut menjadi menit dan detik. Untuk } \\
\text { mengatasi hal ini, subjek menjelaskan beberapa } \\
\text { prinsip matematika yang menjelaskan hubungan } \\
\text { derajat, menit dan detik (SPS1-034) }\end{array}$ & $\begin{array}{l}\text { Kesulitan siswa adalah menentukan bentuk } \\
\text { perbandingan sisi dan ukuran sisi miring segitiga } \\
\text { siku-siku menggunakan rumus phytagoras. Untuk } \\
\text { mengatasi hal ini, subjek menjelaskan posisi sisi } \\
\text { yang belum diketahui, kemudian siswa diminta } \\
\text { menuliskan rumus phytagoras dari segitiga siku-siku } \\
\text { yang diberikan (SPS2-028, SPS2-029) }\end{array}$ \\
\hline
\end{tabular}

Meskipun mengajarkan materi yang berbeda, namun cara subjek mengatasi kesulitan siswa cenderung konsisten. Tabel validasi di atas menunjukkan bahwa subjek selalu menjelaskan prinsip dan aturan-aturan matematik untuk mengatasi kesulitan siswa, baik secara prosedural maupun secara konseptual. Subjek juga melibatkan siswa khususnya dalam hal prosedural seperti perhitungan rumus phytagoras (SPS2-028, SPS2-029). Kemampuan subjek dalam menjelaskan prinsip matematika merupakan salah satu indikasi bahwa subjek menginginkan siswa untuk memahami objek matematika yang bersifat abstrak.

\section{Pembahasan}

Trigonometri adalah bagian dari ilmu matematika yang mempelajari tentang hubungan antara sisi dan sudut suatu segitiga serta fungsi dasar yang muncul dari relasi tersebut. Trigonometri merupakan nilai perbandingan yang didefenisikan sebagai kordinat kartesisus atau segitiga siku-siku. Trigonometri identik dengan fungsi trigonometri yang meliputi sinus (sin) cosinus (cos), tangen (tan), cosecant (cosec), secan dan cotangent (cotan) yang kesemuanya merupakan cara untuk menentukan suatu sisisebuah segitiga atau sudut yang terbentuk dari dua buah sisi dalam segitiga. Dari pembahasan yang terkait dengan perbandingan trigonometri bahwa dalam segitiga siku-sikus salah satu sudut pada segitiga siku-siku $90^{\circ}$. Dalam segitiga siku-siku berlaku teorema pythagoras, kuadrat hipotenusa/sisi miring merupakan jumlah dari kuadrat dua sisi lainnya. Secara sistematis teorema pythagoras dapat dinyatakan sebagai berikut $\mathrm{c}^{\wedge} 2=\mathrm{a}^{\wedge} 2+\mathrm{b}^{\wedge} 2$.

Salah satu pencapaian dalam proses pembelajaran matematika, yaitu hendaknya membantu siswa agar menyajikan konsep yang dipelajarinya dalam berbagai macam model dalam proses pembelajaran matematika sehingga membantu siswa mengembangkan pengetahuan yang lebih mendalam. Hal tersebut yang menunjukkan bahwa kemampuan representasi matematis merupakan salah satu yang harus dipahami siswa dalam mempelajari matematika. representasi situasi masalah tertentu yang ditampilkan siswa dalam bentuk beragam (konsep atau prosedur, bahkan keduanya) sebagai upaya memperoleh kejelasan makna, menunjukkan pemahamannya, atau mencari solusi dari masalah yang dihadapinya.

Representasi bukan hanya menunjuk kepada hasil atau produk yang diwujudkan dalam konfigurasi atau konstruksi baru dan berbeda tetapi juga proses pikir yang dilakukan untuk dapat menangkap dan memahami konsep, operasi, dan hubungan-hubungan matematik dari suatu konfigurasi. Suatu representasi dapat dilihat sebagai suatu konstruksi yang multi-muka yang mengasumsikan peran-peran berbeda tergantung kepada cara siswa berinteraksi dengan representasi tersebut. Siswa dapat berinteraksi dengan representasi sedikitnya dalam dua cara yaitu dengan mengobservasinya atau dengan melakukannya.

Pengetahuan pedagogik dalam penelitian ini dibedakan menjadi dua komponen yaitu komponen pengorganisasian pembelajaran dan komponen strategi pembelajaran. Subjek 
melakukan pembelajaran berkelompok untuk mendidik kerja sama kelompok dan interaksi antarsiswa. Pembelajaran dengan kelompok ini dimaksudkan untuk mempermudah membimbing siswa, agar siswa juga dapat saling bertukar ide maupun gagasan atau saling berinteraksi satu dengan yang lain selama melakukan aktivitas pembelajaran. Hal ini sejalan dengan pendapat Krismanto (2003) bahwa dengan adanya pembagian kelompok maka akan mempermudah siswa melakukan aktivitas pembelajaran, karena siswa dapat berinteraksi dengan siswa lainnya. Melalui pembelajaran ini, setidak-tidaknya terdapat tiga tujuan pembelajaran, yaitu hasil belajar akademik, penerimaan terhadap keragaman, dan pengembangan keterampilan sosial.

Selain pengorganisasian pembelajaran, subjek juga menerapkan strategi pembelajaran ketika mengajarkan konsep trigonometri. Strategi pembelajaran yang dilakukan subjek bertujuan untuk memudahkan penyampaian materi sehingga tujuan pembelajaran dapat dicapai. Strategi bertanya yang dilakukan subjek menekankan kepada proses penyampaian materi secara verbal dari seorang guru kepada siswa dengan maksud agar siswa dapat menguasai materi pelajaran secara optimal. Dalam pelaksanaanya, subjek baik pada pertemuan 1 dan 2 selalu memberikan pertanyaan stimulus yang dapat membangkitkan keterlibatan siswa dalam pembelajaran. Dari pertanyaan-pertanyaan yang diberikan guru kepada siswa untuk membantu meningkatkan kemampuan berpikir siswa dengan mengembangkan proses berpikir siswa. Hal ini sejalan dengan teori dari Hutagaol (2013) yaitu bertanya dalam pembelajaran dipandang sebagai kegiatan guru untuk mendorong, membimbing, dan menilai kemampuan berpikir siswa. Selain itu hasil penelitian Haryani (2011) yang menjelaskan bahwa strategi bertanya dapat dipandang sebagai pembentuk pola pikir matematika dapat melatih dan membiasakan siswa melakukan aktivitas berpikir termasuk berpikir kritis. Dengan bertanya, siswa dilatih untuk memfokuskan pikirannya kepada materi yang disampaikan oleh guru model. Pertanyaanpertanyaan yang diberikan guru kepada siswa untuk membantu meningkatkan kemampuan berpikir siswa dengan mengembangkan proses berpikir siswa.

Selain strategi bertanya, strategi lain yang digunakan oleh subjek adalah diskusi kelompok. Subjek pada pertemuan 1 mengorganisasikan siswa untuk bekerja kelompok namun dalam pelaksanaanya, guru tidak memberikan kesempatan kepada siswa untuk membaca, memahami dan mendiskusikan masalah secara berkelompok. Sedangkan pada pertemuan 2 subjek sudah memberikan kesempatan kepada siswa untuk mengerjakan latihan soal yang diberikan dan mendiskusikan soal bersama teman kelompoknya masing-masing. Dilihat dari pertemuan 1 dan 2, yang dapat membantu siswa dalam mencapai tujuan dari pembelajaran tentang trigonometri adalah dengan adanya diskusi kelompok kecil. Hal ini sejalan dengan apa yang diungkapkan oleh Krismanto (2003) yang mengatakan bahwa diskusi kelompok merupakan suatu upaya bimbingan yang diberikan kepada beberapa individu melalui situasi kelompok, dengan sasaran kelompok tetap adalah individu yang memiliki permasalahan yang sama.

Pada aspek pengetahuan tentang siswa terlihat ada kesulitan dalam mengidentifikasi kesalahpahaman konsep dari siswa sehingga mengatasi miskonsepsi siswa menjadi sulit dilakukan. Hal ini senada dengan apa yang diungkapkan oleh Hulya Kilic (2011) bahwa guru tidak hanya perlu untuk dapat membantu siswa ketika mulai mengalami kesulitan tetapi harus mengetahui sumber kesalahan dan perbaikan penyusunan rencana pengajaran agar tidak menimbulkan kesalahan umum pada siswa. Pembelajaran Matematika yang baik haruslah memperhatikan seluruh aspek termasuk pengetahuan konsep yang benar dan tidak langsung fokus pada aspek prosedural dengan penyelesaian soal soal latihan tanpa membenahi miskonsepsi yang terjadi.

Pengetahuan tentang siswa menyangkut pengetahuan guru tentang konsep-konsep matematika apa yang sulit dipahami siswa, konsep-konsep yang mana siswa biasanya mengalami miskonsepsi, kemungkinan sumber kesalahan siswa, dan bagaimana 
menghilangkan kesulitan-kesulitan dan miskonsepsi itu. Killic (2011) menjelaskan bahwa pengajaran yang didasari oleh pengetahuan tentang siswa tidak hanya mengantarkan informasi prosedural tetapi membantu siswa meningkatkan pemahaman konseptual peserta didik mereka.

Pada proses pembelajaran yang dilakuka subjek, kesulitan-kesulitan atau miskonsepsi yang dialami siswa disebabkan karena pemahaman siswa yang tidak matang terhadap materi luas segitiga. Siswa tidak mampu menghubungkan suatu konsep dengan konsep yang lain dalam menentukan luas segitiga dengan memanfaatkan aturan cosinus. Menurut Suparno dalam Fitria (2014) miskonsepsi yang dialami siswa dapat berbentuk konsep awal, kesalahan hubungan yang tidak benar antara konsep-konsep, gagasan intuitif atau pandangan yang salah.

Mengatasi hal tersebut subjek mengatasi dengan mengulang kembali materi yang diajarkan pada pertemuan sebelumnya. Selain dengan mengulang materi yang telah dipelajari, subjek juga mengatasi kesulitan yang dialami siswa dengan teknik bertanya. Teknik bertanya yang dilakukan subjek untuk membuka wawasan siswa agar dapat dengan mudah memhami materi pelajaran yang diajarkan. Menurut Ma'rufi \& Ilyas (2018) keterampilan bertanya guru penting untuk memahami proses berpikir siswa dan mengantisipasi pengetahuan yang dibutuhkan siswa untuk menganalisis dan memprediksi pemikiran siswa. Dengan pertanyaan, siswa diajari untuk membuat keputusan rasional yang diarahkan untuk memutuskan apakah meyakini atau melakukan sesuatu. Siswa diminta untuk selalu berpikir dengan penuh pertimbangan sebelum meyakini atau melakukan sesuatu. Pertimbangan yang rasional tentu tidak terlepas dari peran logika dan penalaran yang merupakan unsur utama dari proses belajar matematika. Sehingga dengan demikian berpikir kritis dapat mulai dibiasakan pada siswa melalui belajar matematika. Dengan adanya pembiasaan berpikir kritis dalam belajar matematika diharapkan siswa akan dapat menjadi individu yang kritis.

\section{E. Kesimpulan}

Berdasarkan hasil penelitian dan pembahsan di atas maka dapat diambil kesimpulan mengenai Pedagogical Content Knowledge (PCK) mahasiswa perempuan calon guru Matematika berdasarkan Prestasi akademik sebagai berikut:

1. PCK mahasiswa perempuan calon guru Matematika dengan Prestasi akademik tinggi dalam pembelajaran Matematika SMA pada aspek pengeahuan tentang Materi (PM) konsisten pada kemampuan menginformasikan fakta atau simbol matematika, selalu menerangkan konsep matematika dengan jelas dan mampu menjalankan prosedur matematika dengan baik.

2. PCK mahasiswa perempuan calon guru Matematika dengan Prestasi akademik tinggi dalam pembelajaran Matematika SMA pada aspek pengetahuan tentang Pedagogi (PP) konsisten pada kemampuan kemampuan pengorganisasian kelas sehingga pembelajaran dapat berlangsung baik dan dapat selalu memilih strategi pembelajaran yang dapat mendorong siswa untuk aktif dalam belajar.

3. PCK mahasiswa perempuan calon guru Matematika dengan Prestasi akademik tinggi dalam pembelajaran Matematika SMA pada aspek pengetahuan tentang siswa (PS) konsisten pada kemampuan mengatasi miskonsepsi dari siswa dengan baik sehingga kesalahan-kesalahan konsep matematika dapat diluruskan.

4. PCK mahasiswa perempuan calon guru Matematika dengan Prestasi akademik sedang dalam pembelajaran Matematika SMA pada aspek pengetahuan tentang Pedagogi (PP) konsisten pada kemampuan kemampuan pengorganisasian kelas sehingga pembelajaran dapat berlangsung baik dan namun pemilihan strategi pembelajaran masih belum mendorong siswa secara keseluruhan untuk aktif dalam pembelajaran.

5. PCK mahasiswa perempuan calon guru Matematika dengan Prestasi akademik tinggi dalam pembelajaran Matematika SMA pada aspek kemampuan tentang siswa (PS) konsisten pada kemampuan mengatasi miskonsepsi dari siswa walaupun terlihat 
belum maksimal, dan lebih banyak melakukan kediatan menyelesaikan soal-soal latihan.

\section{DAFTAR PUSTAKA}

Fitria, A. 2014. Miskonsepsi mahasiswa dalam menentukan grup pada struktur aljabar menggunakan certainty of response index (CRI) di jurusan pendidikan matematika IAIN antasari (Doctoral dissertation, Universitas Islam Negeri Antasari).

Haryani, S., Prasetya, A. T., \& Rusmawati, D. I. 2016. Pedagogical Content Knowledge (PCK) Calon Guru Dan Guru Kimia Pada Materi Buffer. Unnes Science Education Journal, 5(3).

Hutagaol, K. 2013. Pembelajaran kontekstual untuk meningkatkan kemampuan representasi matematis siswa sekolah menengah pertama. Infinity Journal, 2(1), 85-99.

Ilyas., Marufi, 2017. Tinjauan Teoritis Tentang Pengembangan Pedagogical Content Knowledge Guru Melalui Lesson Study. Journal of Mathematics Education, 2(1),

Kılıç, H. 2011. Preservice secondary mathematics teachers' knowledge of students. Turkish Online Journal of Qualitative Inquiry, 2(2), 17-35.

Krismanto, A. 2003. Beberapa teknik, model, dan strategi dalam pembelajaran matematika. Yogyakarta: Depdiknas Dirjen Pendidikan Dasar dan Menengah.

Loughran, J., Amanda,B. \& Pamela, M. 2012. Understanding and Developing ScienceTeachers' Pedagogical Content Knowledge. Rotterdam: Sense Publisher.

Ma'rufi, Budayasa, I. K., \& Juniati, D. (2018, January). Pedagogical Content Knowledge: Teacher's Knowledge of Students in Learning Mathematics on Limit of Function Subject. In Journal of Physics: Conference Series (Vol. 954, No. 1, p. 012002). IOP Publishing.

Ma'rufi \& Ilyas, M. 2017. Tinjauan Teoritis Tentang Pengembangan Pedagogical Content Knowledge Guru Melalui Lesson Study. Pedagogy: Jurnal Pendidikan Matematika, 2(1).

Ma'rufi \& Ilyas, M. 2018. Mentoring Guru dalam Pembelajaran Matematika Berbasis Pedagogical Content Knowledge. Prosiding, 3(1).

Pasandaran, R. F., Kartika, D. M. R., \& Masni, E. D. 2018. PENGEMBANGAN LEMBAR KERJA MAHASISWA (LKM) PADA PEMBUKTIAN DALIL-DALIL SEGITIGA. Prosiding, 3(1).

Shulman, L.S. 1986. Those Who Understand: Knowledge growth in teaching. Educational Research, Vol. 15(2), 1986.

Turnuklu, E. B., \& Yesildere, S. 2007. Content Knowledge. IUMPST: The Journal, 1, 1-13. 